\title{
Nontraditional Prospective Teachers: Motivations, Goals and Mathematical Knowledge Differences among Identified Typologies
}

Margareta M. Thomson, PhD \& Valerie N. Faulkner, PhD, NC State University

\section{ABSTRACT}

This mixed-methods study employed a typological approach and an Expectancy-Value framework to understand nontraditional prospective teachers' motivational beliefs, teaching motivations, and goals for choosing a teaching career. All participants $(N=88)$ were nontraditional prospective teachers, graduate students enrolled in a Master of Arts in Teaching (MAT) program in the United States. Data were collected in three phases, including quantitative (survey, pre-and posttest assessments), and qualitative (interviews). Analyses revealed three distinct typologies of teachers based on their motivational beliefs, and further differences among the identified groups based on other variables. The qualitative data showed general themes across participants about their teaching efficacy, motivation for teaching and quality of teacher preparation. Implications for teacher education programs are discussed.

Keywords: teacher education, motivational beliefs, motivation, goals

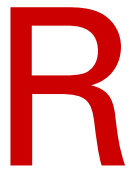
ecent research and national reports (e.g., Thomson \& Palermo, 2018; Feistritzer, 2011) showed that about $65 \%$ of United States teachers entering the profession were traditional prospective teachers who had completed a traditional undergraduate teacher education program, but the remaining $35 \%$ of teachers were nontraditional prospective teachers. Thus, nontraditional prospective teachers, who have been prepared to teach either through a traditional graduate teacher education program, or via alternative teaching certification programs, currently constitutes a fairly large percentage in the total teacher population across the U.S. (Feistritzer, 2011). Nontraditional prospective teachers in the current study are described as teacher candidates for whom teaching was not their first career choice. While much research is conducted with traditional prospective teachers, there is a scarcity of research conducted with nontraditional prospective teachers, especially about their motivational beliefs (i.e., efficacy), career and academic goals, 
and how these impacts their career views and professional path (Thomson \& Palermo, 2014; Thomson \& Palermo, 2018; Thomson, Gray, Walkowiak, \& Alnizami, 2021).

Practice and research suggest that very often teachers' classroom decisions are solidly grounded in their teaching beliefs and motivation (Berger \& Girardet, 2020; Brookhart \& Freeman, 1992; Watt \& Richardson, 2012). Along with their content expertise, what motivates individuals to teach and what beliefs and values they hold about teaching are at the core of teachers' professional identities, classroom practices, and their ongoing capacity for professional development (Bandura, 1977; Bryan, 2003). Moreover, the individual and group differences regarding teaching motivation, teaching motivational beliefs (such as efficacy for teaching) or personality traits, can provide a better picture of the variation in teachers' views and attitudes about teaching (Thomson, Turner, \& Nietfeld, 2012; Watt \& Richardson, 2007, 2008)

The typological approach in our study, using an Expectancy-Value approach, examines empirically identified typologies of prospective teachers (PTs) based on their motivational beliefs and establishes how these typologies differ with respect to other variables. A typological approach to investigating teacher motivation has the potential to be used to provide valuable information to teacher education programs regarding PT candidates and to $\mathrm{K}-12$ schools in their mentoring of novice teachers. Specifically, the current mixed-methods study investigates PTs' typologies based on their general-and mathematics- efficacy beliefs and existing differences between typologies with respect to various characteristics, such as teaching motivations, academic goals, mathematics pedagogical and content knowledge (PCK), and personality traits. Survey and interview data were collected from nontraditional prospective teachers, graduate students $(N=88)$ enrolled in a Master's Teacher Training (MAT) program with a major university in the US. Specific research questions addressed by this study are the following:

1. What typologies of PTs (i.e., clusters) were identified based on participants' ratings on their general- and domain specific- efficacy beliefs?

2. How are demographic characteristics (i.e., gender, age, year of study, career intentions and commitment to teaching) relevant across the identified typologies?

3. How are the identified typologies different with respect to characteristics, such as teaching motivations, academic goals, and personality traits? 
4. Are the identified typologies different with respect to their mathematics achievement (pre- and posttest mathematics knowledge test)?

5. How do participants describe their teacher training experiences in the MAT program?

\section{Theoretical Framework}

The Expectancy-Value Theory (EVT) beginning with Atkinson (1957) is one of the major frameworks for achievement motivation. Generally, research in this area has regarded success expectancies and task valuation as major elements to determine motivational engagement and subjective values of tasks (Wigfield \& Eccles, 2000; Wigfield, Tonks, \& Eccles, 2004). The Expectancy-Value Theory is based on the notion that a person's motivation to perform a behavior is the product of his/her expectations to perform the task (i.e., meet a goal) and the perceived value of that goal (Atkinson, 1964; Eccles, Kaczala, \& Meece, 1982; Eccles, 2005). One's values and expectancies are key motivational components in predicting academic behaviors and choices. Wigfield and Eccles $(1992,2000)$ researched the concept further to explain that an individual's choice of tasks or goals, their persistence, and their performance can be explained by determining the individuals' expectancy and value concerning mastering the task or obtaining the goal. Two key concepts are discussed in the Expectancy-Value Theory: (1) the concept of value and (2) expectancies (expectancies for success or ability beliefs).

\section{Values}

The concept of value, central to the Expectancy-Value Theory, is differentiated into components of (a) intrinsic value, (b) utility value, (c) attainment value and (d) cost (Wigfield \& Eccles, 1992, 2000). The first component (a) intrinsic value refers to the emotional element (e.g., enjoyment in performing a task); the second component (b) utility value refers to how a task will be useful to an individual (e.g., task relevance for the individual); the third component (c) attainment value refers to the subjective importance of doing well in a task (e.g., personal meaning) and fourth component (d) cost value refers to the effort required (e.g., the cost of achieving the task). 


\section{Expectancies (Ability Beliefs)}

The other key component of the Expectancy-Value Theory is the concept of expectancies (expectancies for success or ability beliefs) which are the perceptions of one's competence at a given activity. Wigfield and Eccles (2000) proposed three higher order constructs: (1) expectancy/beliefs; (2) subjective task value (i.e., attainment, intrinsic and utility values), and (3) perceived task difficulty (i.e., effort required and task difficulty). Given the fact that most empirical research investigating different components of the Expectancy-Value Theory were used in the context of academic achievement tasks with students (e.g., gender differences regarding mathematical performance), the current study brings a contribution to the field by investigating elements of EVT with teachers in a teacher education/professional development context (especially teacher goal development, career choices).

\section{Methods}

\section{Participants and Procedures}

Participants $(N=88)$ in the current study were nontraditional prospective teachers enrolled in the Elementary MAT program at a major US university; all were seeking a K-5 teaching certification. In the MAT program, the nontraditional prospective teachers do not have undergraduate degrees in educational fields, thus they transition from other domains into teaching. Demographics of participants indicated that most were females $(98 \% ; n=85)$ and ranged in age from the early 20 s to the mid-30s.

Data were collected using surveys from all participants $(N=88)$ and interviews with a small number of participants $(n=10)$ from the larger sample. Only 10 participants from the pool of survey participants agreed to an interview. The study took place in 3 distinct phases (see Appendix A), namely: phase 1: pretest, phase 2: posttest, and phase 3: interviews.

\section{Results}

\section{Teacher Typologies}

Results from the cluster analysis (see Appendix B) identified three typologies of PTs (i.e., clusters) based on participants' ratings on their general and mathematics teaching efficacy beliefs. Cluster 1 ( $n=39$ ) obtained the highest scores on all efficacy dimensions (TSE general score and all 3 subscales) compared to the other two clusters, except for the mathematics personal efficacy subscale, suggesting that participants from this cluster feel 
very confident in general about their teaching abilities, but less confident about their mathematics teaching abilities. Cluster $2(n=34)$ obtained the highest scores relative to the other two clusters on the general teaching self-efficacy scale (TSE) and on the mathematics personal efficacy subscale, suggesting that they feel very confident about teaching in general and about their mathematics teaching abilities. Cluster $3(n=15)$ generally obtained the lowest scores compared to the other two clusters on all efficacy dimensions. This group obtained the lowest scores on the general teaching measure (TSE) and on the mathematics personal efficacy subscale, suggesting that they feel less confident about teaching in general and particularly, about their mathematics teaching.

Additional Pearson Chi-square results (see Appendix C) indicated no significant differences between prospective teachers' typologies (clusters) based on age ( $p=.934)$, gender $(p=.759)$, year of program ( $p=.092)$, career intention ( $p=.074)$ or commitment to teaching $(p=.495)$. These results suggest that cluster profiles are solely formed based on participants' efficacy beliefs and not on their demographics.

\section{Personality, Motivations and Goal Differences among Typologies}

To determine differences among typologies based on participants' characteristics such as personality traits, teaching motivations, and academic goals, one-way MANOVA was conducted with cluster membership as the independent variable. Significant differences between clusters $\left(F(2,18)=2.07, p<.01, \eta^{2}=.197\right)$ were found for these variables (see Appendix D).

MANOVA results revealed a significant main effect of cluster membership and personality traits (Openness scale, $F(2,84)=6.40, p=.003, \eta^{2}=.132$ ). Post Hoc Bonferroni test showed that Cluster $1(M=3.33, S D=.37)$ scored significantly higher $(p<.005)$ on Openness scale than Cluster $2(M=3.03, S D=.35)$, and Cluster 1 members scored marginally higher ( $p=.065)$ than Cluster 3 members $(M=3.06, S D=.43)$. No significant differences were found between the three clusters with respect to their teaching motivations or their academic goals.

\section{Mathematics Knowledge among Typologies}

Pre-test and post-test scores for the mathematics knowledge test (LMT) were used to calculate differences among participants overall scores from pre- to post-test, and differences among the identified three clusters regarding their mathematics knowledge (see Appendix E). With respect to participants $(N=88)$ overall pre- post test scores, ANOVA analysis found no 
significant differences between overall IRT scores from pretest $(M=-.061 ; \mathrm{SD}=.622)$ to posttest ( $M=.342 ; S D=.798)$, however an increase in participants' scores was observed from pretest to posttest (gain in scores of 0.281 ). With respect to participants scores depending on cluster membership (typology), significant differences were found at pretest between participants' scores ( $p=.042$ ), but no significant differences were found at posttest. Cluster 1 participants had slightly significant scores at pretest $(M=.025 ; S D=.675)$ compared to Cluster 2 participants ( $M=-.359 ; S D=.400)$. No other significant differences were found between clusters with respect to their mathematical knowledge.

\section{Narrative Accounts}

Qualitative results from the interviews describe participants' teaching efficacy beliefs, motivations for teaching and their teacher training experiences in the MAT program. Two common themes across all interview participants $(n=10)$ were identified, namely: Growth and Inclusivity.

Growth. Generally, all participants talked about learning a great deal about mathematics teaching and teaching during their MAT program. Generally, they expressed increased efficacy throughout the program, especially for the mathematics teaching. One participant stated: "And so I feel just from that I'm more prepared to teach math then I ever was, especially considering it's not one of my favorite subjects, but that was one of my favorite classes."

Another student said “....in general I'm about ready to start student teaching, I am pretty confident, but I know that there are definitely going to be challenges along the way and that I myself am going to have to be a learner in this process, probably for however long I'm in the classroom, I'm definitely going to be a learner as well as a teacher."

Inclusivity. Additional interview data on their reflections on the program preparation showed that while participants recognized professional growth during their teacher preparation program, in their methods courses they were exposed to challenging, yet new ideas about equity in mathematics teaching. Participants illustrate this idea by reflecting on their new vision of mathematics teaching: "The teacher has opened my eyes to seeing what is going on with mathematics and the tracking that's going on [in K-12 schools]. And how we should include all the diversities in one classroom... and how there are just so many ways 
how to teach a certain topic in math and the class has taught us that ... math can be taught in the wrong way."

Another student stated, "what I've learned in my math methods course it's going to make a little more sense not just to the teacher, but the student too hopefully."

\section{Conclusion}

Research literature on teacher beliefs and practices (i.e., Hayes, 2002; Smith, Southerland, 2007) shows that despite a history of reform initiatives, science and mathematics continues to be one of the most neglected subjects in the elementary school curriculum. Research shows that relatively few elementary teachers report that they are adequately academically prepared to teach science and mathematics effectively (Cerniak, Lumpe, 1996); moreover, research shows that most elementary teachers hold negative attitudes about teaching these subject matters which contributes to their dissatisfaction with their profession (Corbel et al., 2008, 2010a, 201b).

The current study is a response to the need for more thoroughly investigating elementary teachers' views of teaching and their impact on teaching practices in critical areas such as mathematics. At the same time, examining nontraditional prospective teachers will help educators better understand various aspects of motivation among career switchers, like the nontraditional teachers entering the teaching field.

Results from the current study showed that not all nontraditional teacher candidates enter the teacher education program with the same level of efficacy regarding their general teaching abilities, or their domain specific teaching efficacy beliefs (i.e., mathematics teaching efficacy beliefs in this case). Also, study results show that participants may exhibit different innate abilities, such as specific personality characteristics, which may indirectly impact their attitudes toward teaching and their beliefs about teaching. Cluster 1, which had the highest scores on all general teaching efficacy dimensions (i.e., TSE and the 3 subscales), compared to the other two clusters also show significantly higher scores on personality subscale of Openness. With respect to mathematics knowledge, significant differences were found between clusters at pretest only (Cluster 1 and Cluster 3), but not at posttest, suggesting that participants entered the course with slightly different levels of knowledge, but at the end of the course, they had overall, a similar body of knowledge. Also, with respect to participants overall mathematics knowledge, there were no pre-posttest significant differences, but an 
increase of knowledge was observed (a gain of 0.281 ) which suggest that participants overall made gains in mathematics knowledge, however a statistical value (ex. $p$ values calculated based on $\mathrm{Cl}$ of $95 \%$ ) does not capture entirely the realities of classroom practice.

\section{Implications and Future Research}

The current study contributes to the field by looking at the characteristics, including mathematical content knowledge, of nontraditional prospective teachers. Study participants, the nontraditionally prospective teachers, are a growing minority of those entering the field of teaching and examining aspects related to their teacher training is critical.

The delineation of the identified clusters in the current study serves to better understand the 'types' of characteristic profiles one can expect as they educate these teachers in mathematics content and pedagogy courses. Study findings suggests that a substantial group of prospective nontraditional teachers who demonstrate high confidence in general, might question their ability in teaching mathematics (Cluster 1). This group also scores the highest in openness. Educators may learn to 'lean on' this group because of their tendency towards this disposition. The combination of these characteristics is valuable in a math methods and pedagogy class because this group may demonstrate the openness and confidence to discuss publicly their own understandings of the mathematics which they have identified as a weakness within themselves.

Furthermore, encouraging prospective teachers to question their own understandings will support those whose confidence is low across the board. Seeing confident role models discuss their misunderstandings of the mathematics may help to create an environment that allows less confident prospective teachers to engage in their own misunderstandings by seeing that they are not alone in their confusion.

At the same time, mathematical content knowledge, as a characteristic of the teacher's profile, is not related to teacher's own confidence in their own ability. This also has classroom considerations for those working with this population. It is important for those who work with this population to remember that reported ability and confidence in mathematics does not correlate to actual strength in mathematics. Are there ways that a professor might find to help students better understand their own mathematical understandings? Paying attention to this need, to better help prospective teachers evaluate their own mathematical understandings, 
may create a more open environment where misunderstandings, error, and growth are all a grounded part of the classroom conversation.

Future research can further examine how teacher characteristics such as motivation, efficacy, and content knowledge has an impact on the quality of teacher training, and if these factors contribute to alleviating teacher attrition. Contributions from such research could provide insights to teacher education programs (i.e., regarding PTs' motivations and perceptions), the teaching profession, (i.e., workplace factors), or both.

\section{About the Authors}

Margareta M. Thomson, PhD is a Professor of Educational Psychology in the department of Teacher Education and Learning Sciences (TELS) at North Carolina State University. Valerie N. Faulkner, PhD is a Professor of Mathematics Education in the department of Teacher Education and Learning Sciences (TELS) at North Carolina State University.

\section{References}


Atkinson, J.W. (1957). Motivational determinants of risk-taking behavior. Psychological Review, 64, 359-372.

Atkinson, J.W. (1964). An introduction to motivation. Princeton, NJ: Von Nostrand.

Akerson, L.A., \& Donnelly, L.A. (2008). Relationship among learner characteristics and preservice elementary teachers' views of nature of science. Journal of Elementary Science Education, 20 (1), 45-58.

Bandura, A. (1977). Self-efficacy: toward a unifying theory of behavioral change. Psychological Review, 84, 191-215.

Berger, J-L. \& Girardet, C. (2020). Vocational teachers' classroom management style: the role of motivation to teach and sense of responsibility. European Journal of Teacher Education, 1-17.

Brookhart, S. M., \& Freeman, D. J. (1992). Characteristics of entering teacher candidates. Review of educational research, 62(1), 37-60.

Bryan, L.A. (2003). Nestedness of beliefs: Examining a prospective elementary teachers' belief system about science teaching and learning. Journal of Research in Science Education, 17, 357-369.

Czerniak, C. M., \& Lumpe, A. T. (1996). Relationship between teacher beliefs and science education reform. Journal of Science Teacher Education, 7(4), 247-266.

Corbell, K.A., Booth, S., \& Reiman, A.J. (2010). The commitment and retention intentions of traditionally and alternatively licensed math and science beginning Teachers. Journal of Curriculum and Instruction, 4(1), 50-69.

Corbell, K.A., Osborne, J., \& Reiman, A.J. (2010). Supporting and retaining beginning teachers: A validity study of the Perceptions of Success Inventory for Beginning Teachers. Educational Research and Evaluation, 16(1), 75-96.

Corbell, K.A., Reiman, A.J., \& Nietfeld, J.L. (2008). The Perceptions of Success Inventory for Beginning Teachers: Measuring its psychometric properties. Teaching and Teacher Education, 24(6), 1551-1563. 
Costa, P.T.,Jr. \& McCrae, R.R. (1992). Revised NEO Personality Inventory (NEO-PI-R) and NEO Five-Factor Inventory (NEO-FFI) manual. Odessa, FL: Psychological Assessment Resources.

Deci, E. L. \& Ryan, R. M. (2000). The what and why of goal pursuits: Human needs and the self-determination of behavior. Psychology Inquiry, 11(4), 227-268.

Eccles, J. S. (2005). Subjective task value and the Eccles et al. model of achievement-related choices. Handbook of competence and motivation, 105-121.

Enochs, L. G., \& Riggs, I.M. (1990). Further development of an elementary science teaching efficacy beliefs instrument: A preservice elementary scale. School Science and Mathematics, 90, 94-706.

Feistritzer, E. C. (2011). Profiles of teachers in the U.S. National Center for Education Information. Retrieved from http://www.edweek.org/media/pot2011final-blog.pdf

Hayes, M. T. (2002). Elementary preservice teachers' struggles to define inquiry-based science teaching. Journal of Science Teacher Education, 13 (2), 147-165.

Parsons, J. E., Kaczala, C. M., \& Meece, J. L. (1982). Socialization of achievement attitudes and beliefs: Classroom influences. Child development, 322-339.

Smith, L. K., \& Southerland, S. A. (2007). Reforming practice or modifying reforms? Elementary teachers' response to the tools of reform. Journal of research in science teaching, $44(3)$, 396-423.

Thomson, M. M., Turner, J.E., \& Nietfeld, J. (2012). A typological approach to investigate motivation for teaching and beliefs about teaching of preservice teacher candidates. Teaching and Teacher Education, 28, 324-335.

Thomson, M.M. \& Palermo, C. (2014). Preservice teachers' understanding of their professional goal: Case studies from three different typologies. Teaching and Teacher Education,44, 56-68.

Thomson, M.M., \& Palermo, C. (2018). Using an expectancy-value model to understand teaching motivation among nontraditional preservice teachers: A phenomenological study approach. Action in Teacher Education, 40 (2),151-168. 
Thomson, M.M., Gray, D., Walkowiak, T. \& Alnizami, R. (2021). Developmental trajectories for elementary novice teachers: Teaching efficacy and mathematics knowledge. Journal of Teacher Education, 1-14. https://doi.org/10.1177\%2F00224871211014128

Tschannen-Moran, M., \& Woolfolk Hoy, A. (2001). Teacher efficacy: Capturing and elusive construct. Teaching and Teacher Education, 17, 783-805.

Watt, H.M.G. \& Richardson, P. W. (2007). Motivational factors influencing teaching as a career choice: Development and validation of the FIT-Choice Scale. The Journal of experimental education, 75(3), 167-202.

Watt, H.M.G. \& Richardson, P. (2008). Motivations, perceptions, and aspirations concerning teaching as a career for different types of beginning teachers. Learning and Instruction, $18,408-426$.

Watt, H.M.G., Richardson, P.W., Klusmann, U., Kunter, M., Beyer, B., Trautwein, U., \& Baumert, J. (2012). Motivations for choosing teaching as a career: An international comparison using the FIT-choice scale. Teaching and Teacher Education, 28, 791-805.

Wigfield, A., \& Eccles, J. S. (1992). The development of achievement task values: A theoretical analysis. Developmental review, 12(3), 265-310.

Wigfield, A. \& Eccles, J. S. (2000). Expectancy-value theory of achievement motivation. Contemporary Educational Psychology, 25, 68-81.

Wigfield, A., Tonks, S., \& Eccles, J. S. (2004). Expectancy value theory in cross-cultural perspective. In Research on sociocultural influences on motivation and learning (pp. 165198). New York, NY: Information Age Publishing, Inc. 


\section{Appendix A}

Data sources and procedures

\begin{tabular}{|c|c|}
\hline Quantitative measures & Instruments \& Subscales \\
\hline \multicolumn{2}{|l|}{$\begin{array}{l}\text { Phase 1: Pretest (beginning of } \\
\text { semester) }\end{array}$} \\
\hline \multicolumn{2}{|l|}{ Demographic data } \\
\hline $\begin{array}{l}\text { Mathematics pedagogical and content } \\
\text { knowledge (PCK) } \\
\text { Learning Mathematics for Teaching } \\
\quad \text { (LMT; Hill \& Ball, 2004) }\end{array}$ & $\begin{array}{l}\text { Learning Mathematics for Teaching }(L M T) \\
\text { Multiple-choice test } \\
\text {-Form A pretest ( } 13 \text { items, alpha }=.53 \text { ) }\end{array}$ \\
\hline \multicolumn{2}{|l|}{ Phase 2: Posttest (end of semester) } \\
\hline \multicolumn{2}{|l|}{ Demographic data } \\
\hline $\begin{array}{l}\text { Motivation for teaching } \\
\text { Reasons for Teaching Scale (RTS; } \\
\text { Thomson \& el., 2012) }\end{array}$ & $\begin{array}{l}\text { Reasons for Teaching Scale (RTS) } \\
\text { Likert scale items from 1-6 (RTS overall alpha }=.70) \\
\text {-Intrinsic motives (4 items, alpha }=.71) \\
\text {-Extrinsic motives (6 items, alpha }=.73 \text { ) } \\
\text {-Social influences ( } 2 \text { items, alpha }=.69)\end{array}$ \\
\hline $\begin{array}{l}\text { Academic and career goals (ACG; Turner } \\
\text { et al., unpublished) }\end{array}$ & $\begin{array}{l}\text { Academic and career goals (ACG) } \\
\text { Likert scale items from 1-6 } \\
\text { (8 items, alpha }=.70 \text { ) }\end{array}$ \\
\hline $\begin{array}{l}\text { Teacher's Sense of Efficacy Scale (TSE; } \\
\text { Tschannen-Moran, \& Woolfolk Hoy, 2001) }\end{array}$ & $\begin{array}{l}\text { Teacher's Sense of Efficacy Scale (TSE) } \\
\text { Likert scale items from 1-9 (TSE overall alpha }=.82 \text { ) } \\
\text {-Student Engagement (4 items, alpha }=.74 \text { ) } \\
\text {-Instructional Strategies ( } 4 \text { items, alpha }=.82 \text { ) } \\
\text {-Classroom Management (4 items, alpha }=.69 \text { ) }\end{array}$ \\
\hline $\begin{array}{l}\text { Teaching Mathematics Self-Efficacy } \\
\text { Mathematics Teaching Efficacy Beliefs } \\
\text { Instrument (MTEBI; Enochs \& Riggs, } \\
\text { 1990). }\end{array}$ & $\begin{array}{l}\text { Mathematics Teaching Efficacy Beliefs Instrument } \\
\text { Likert scale items from 1-5 (MTEBI overall alpha = .81) } \\
\text {-Personal Efficacy (PE), (13 items, alpha = .84) } \\
\text {-Outcome Expectancy (OE), (8 items, alpha =.61) }\end{array}$ \\
\hline $\begin{array}{l}\text { NEO-Five Factor Inventory } \\
\text { (NEO-FFI-3 Personality Test; McCrae \& } \\
\text { Costa, 2010) }\end{array}$ & $\begin{array}{l}\text { NEO-FFI-3 Personality Test } \\
\text { Likert scale items from } 1-5 \text { (NEO-FFI overall alpha = .79) } \\
\text { - Neuroticism (12 items, alpha }=.79) \\
\text { - Extraversion (12 items, alpha }=.76) \\
\text { - Openness (10 items, alpha }=.45) \\
\text { - Agreeableness (4 items, alpha }=.48) \\
\text { - Conscientiousness ( } 12 \text { items, alpha }=.72 \text { ) }\end{array}$ \\
\hline $\begin{array}{l}\text { Mathematics pedagogical and content } \\
\text { knowledge (PCK) } \\
\text { Learning Mathematics for Teaching } \\
\text { (LMT; Hill \& Ball, 2004) }\end{array}$ & $\begin{array}{l}\text { Learning Mathematics for Teaching (LMT) } \\
\text { Multiple-choice test } \\
\text {-Form C posttest ( } 11 \text { items, alpha }=.65 \text { ) }\end{array}$ \\
\hline Qualitative measures & Short description \\
\hline \multicolumn{2}{|c|}{ Phase 3: Interviews (end of semester) } \\
\hline Semi-structured interviews & Face-to-face or phone interviews (appx 45-50 min) \\
\hline
\end{tabular}




\section{Appendix B}

Cluster profiles based on efficacy beliefs $(N=88)$

\begin{tabular}{|c|c|c|c|c|c|}
\hline & $\begin{array}{c}\text { Cluster } 1 \\
(n=39)\end{array}$ & $\begin{array}{c}\text { Cluster } 2 \\
(n=34)\end{array}$ & $\begin{array}{c}\text { Cluster } 3 \\
(n=15)\end{array}$ & & \\
\hline & Mean & Mean & Mean & $F$ & $p<$ \\
\hline $\begin{array}{l}\text { TSE total } \\
\text { score }\end{array}$ & 8.44 & 7.43 & 7.11 & 111.214 & $.000 * * *$ \\
\hline $\begin{array}{l}\text { TSE Student } \\
\text { engagement }\end{array}$ & 8.49 & 7.24 & 7.53 & 42.449 & $.000 * * *$ \\
\hline $\begin{array}{l}\text { TSE } \\
\text { Instructional } \\
\text { strategies }\end{array}$ & 8.47 & 7.73 & 6.37 & 79.539 & $.000 * * *$ \\
\hline $\begin{array}{l}\text { TSE } \\
\text { Classroom } \\
\text { management }\end{array}$ & 8.35 & 7.31 & 7.43 & 25.650 & $.000 * * *$ \\
\hline MTEBI & 3.90 & 3.82 & 3.56 & 4.367 & $.016^{* *}$ \\
\hline $\begin{array}{l}\text { MTEBI } \\
\text { Personal self- } \\
\text { efficacy }\end{array}$ & 3.94 & 3.97 & 3.47 & 6.009 & $.004^{* *}$ \\
\hline $\begin{array}{l}\text { MTEBI } \\
\text { Outcome } \\
\text { expectancy }\end{array}$ & 3.84 & 3.58 & 3.70 & 3.265 & $.043^{*}$ \\
\hline
\end{tabular}

Note: TSE=Teaching self-efficacy; $M T E B I=M a t h e m a t i c s$ teaching efficacy beliefs instrument 


\section{Appendix C}

Cluster membership and demographics $(N=88)$

\begin{tabular}{crrrrr}
\hline & \multicolumn{5}{c}{ Cluster membership* } \\
\hline Variable & \multicolumn{1}{c}{ Age } & \multicolumn{1}{c}{ Gender } & Year P & Career Int & Commitment \\
Chi-square & 4.27 & .55 & 13.63 & 5.21 & 141.55 \\
$p$ & .934 & .759 & .092 & .074 & .495
\end{tabular}

Note: Year of prg=Year in the teacher education program; Career Int=Career Intention 


\section{Appendix D}

Cluster differences on personality traits, goals, and motivations $(N=88)$

\begin{tabular}{|c|c|c|c|c|c|c|c|}
\hline & Cluster & $n$ & $M$ & $S D$ & $F$ & $p$ & $\eta_{p}^{2}$ \\
\hline \multirow[t]{4}{*}{ Neuroticism } & 1 & 38 & 2.47 & .59 & 2.33 & .103 & .053 \\
\hline & 2 & 34 & 2.73 & .42 & & & \\
\hline & 3 & 15 & 2.66 & .56 & & & \\
\hline & Total & 87 & 2.61 & .53 & & & \\
\hline \multirow[t]{4}{*}{ Extraversion } & 1 & 38 & 3.91 & .46 & 2.04 & .137 & .046 \\
\hline & 2 & 34 & 3.68 & .40 & & & \\
\hline & 3 & 15 & 3.75 & .63 & & & \\
\hline & Total & 87 & 3.79 & .48 & & & \\
\hline \multirow[t]{4}{*}{ Openness } & 1 & 38 & 3.33 & .37 & 6.40 & $.003^{* *}$ & .132 \\
\hline & 2 & 34 & 3.03 & .35 & & & \\
\hline & 3 & 15 & 3.06 & .43 & & & \\
\hline & Total & 87 & 3.17 & .40 & & & \\
\hline \multirow[t]{4}{*}{ Agreeableness } & 1 & 38 & 4.39 & .46 & 1.07 & .346 & .025 \\
\hline & 2 & 34 & 4.41 & .26 & & & \\
\hline & 3 & 15 & 4.23 & .54 & & & \\
\hline & Total & 87 & 4.37 & .41 & & & \\
\hline \multirow[t]{4}{*}{ Conscientiousness } & 1 & 38 & 4.04 & .51 & 1.95 & .149 & .044 \\
\hline & 2 & 34 & 3.99 & .32 & & & \\
\hline & 3 & 15 & 3.77 & .46 & & & \\
\hline & Total & 87 & 3.97 & .44 & & & \\
\hline \multirow[t]{4}{*}{ Extrinsic motivation } & 1 & 38 & 3.11 & .86 & 1.49 & .231 & .034 \\
\hline & 2 & 34 & 3.07 & .82 & & & \\
\hline & 3 & 15 & 2.68 & .94 & & & \\
\hline & Total & 87 & 3.02 & .86 & & & \\
\hline
\end{tabular}




\begin{tabular}{llllllll}
\hline Intrinsic motivation & 1 & 38 & 5.28 & .62 & 2.63 & .078 & .059 \\
& 2 & 34 & 4.95 & .69 & & & \\
& 3 & 15 & 4.95 & .69 & & & \\
& Total & 87 & 5.09 & .67 & & & \\
\hline Social motivation & 1 & 38 & 3.34 & 1.41 & .81 & .448 & .019 \\
& 2 & 34 & 3.29 & 1.31 & & & \\
& 3 & 15 & 2.83 & 1.28 & & & \\
Academic goals & Total & 87 & 3.24 & 1.35 & & & \\
& 1 & 38 & 3.86 & .65 & .66 & .519 & .015 \\
& 2 & 34 & 3.87 & .77 & & & \\
& 3 & 15 & 3.62 & .88 & & & \\
& Total & 87 & 3.82 & .74 & & & \\
\hline
\end{tabular}




\section{Appendix E}

Overall and Cluster differences on math test IRT scores

\begin{tabular}{|c|c|c|c|c|c|c|c|}
\hline & Overall & $n$ & $M$ & $S D$ & $F(d f)$ & $p$ & $\eta_{p}^{2}$ \\
\hline $\begin{array}{l}\text { LMT Score pre-test } \\
\text { (Form A) }\end{array}$ & & 85 & -.061 & .067 & 1.55 & .108 & .267 \\
\hline $\begin{array}{l}\text { LMT Score post-test } \\
\text { (Form C) }\end{array}$ & & 88 & .342 & .798 & & & \\
\hline
\end{tabular}

LMT Score pre-test

(Form A)

$\begin{array}{llll}\text { Cluster } \mathrm{n} & \mathrm{M} \quad \mathrm{SD} & \begin{array}{l}\text { Combined/ } \\ \text { Linear }\end{array}\end{array}$

\begin{tabular}{lllllll}
\hline & 1 & 38 & $.025 \mathrm{a}$ & .675 & $2.04(2) /$ & $.136 /$ \\
& 2 & 33 & -.035 & .618 & $3.99(1)$ & $.049^{*}$ \\
& 3 & 14 & $-.359 \mathrm{~b}$ & .400 & & \\
& Total & 85 & -.061 & .067 & & \\
\hline LMT Score post-test & & & & & $\mathrm{F}(\mathrm{df})$ & \\
(Form C) & Cluster & $\mathrm{n}$ & $\mathrm{M}$ & $\mathrm{SD}$ & Combined/ & $\mathrm{p}$ \\
& & & & & Linear & \\
\hline & 1 & 39 & .269 & .874 & $.797(2) /$ & $.454 /$ \\
& 2 & 34 & .476 & .790 & $.031(1)$ & .861 \\
& 3 & 15 & .226 & .582 & & \\
& & & &
\end{tabular}

Note: Values with different subscripts ( $a$ and $b$ ) denotes significant differences between these clusters $(p=.042)$ 